\title{
Biological control of subterranean termites (Psammotermes hypostoma ) by entomopathogenic fungi
}

\author{
Mahmoud M.M. Soliman ${ }^{1 *}$, Rafat Khalaph Allah' ${ }^{2}$, Mohamed Hammad ${ }^{3}$, A. A. Ebnalwaled ${ }^{4}$ \\ ${ }^{1}$ Department of plant protection, Faculty of Agriculture, Beni-Suef University, Beni-Suef, Egypt \\ ${ }^{2}$ Department of Botany (Microbiology), Faculty of Agriculture, South Valley University, Qena, Egy \\ ${ }^{3}$ Department of plant protection, Faculty of Agriculture, South Valley University, Qena, Egypt \\ ${ }^{4}$ Department of physics, Faculty of science, South Valley University, Qena, Egypt \\ *corresponding author: e-mail: solimanapp@gmail.com
}

\begin{abstract}
This study is conducted to determine the effect of entomopathogenic fungi Metarhiziuim anisopliae ( M. ani), Beauveria bassiana (B.bas) and Aspergillus niger (A.niger) in some aspects subterrenene termites life under laboratory and field conditions. After one week of treatment there was significate difference among concentrate $4 \times 106$ and concentrates $2 \times 106$ and $1 \times 106$ but no significate difference among concentrates $2 \times 106$ and $1 \times 106$ of all treatments. In addition to there was significant difference among M.anisopliae and other fungi B.bassiana (Ballsamo) and A.niger, The fungi M.ansiopliae more effectiveness than B.bassiana and A.niger which the mortality rates were $22.5 \%, 15.0 \%$ and $13.3 \%$ to M.ansiopliae , B.bassiana and A.niger respectively. The LC50 for three fungi were $3.278 \times 106,4.6526 \times 106$ and 5.4982 $\times 106$ for M.anisopliae, B.bassiana and A.niger, respectively. The higher concentrations $2 \times 106 \mathrm{spores} / \mathrm{ml}$ and $4 \times 106$ spores $/ \mathrm{ml}$ the reduction percentages were $25.93,19.43$ and $11,85 \%$ for $2 \times 106 \mathrm{spores} / \mathrm{ml}$ and $61.52,35.54$ and $20.06 \%$ at $4 \times 106$ spores $/ \mathrm{ml}$ for A.niger, B.bassiana and M.anisopliae, respectively . The run-down in the reduction $\%$ in treated traps with M. anisopliae concentrations of may be due to this reason. The reduction percentages for trap treated with concentrations of A. niger were height due to not attack by workers, due to the fungi A. niger has a repellent or an antipathetic effect to worker.
\end{abstract}

KEYWORDS: Nanomaterial or Nanotechnology - Termites - Antibiotic - Pests management - Pesticides.

\section{INTRODUCTION}

Termites are classified into two groups, subterranean and dry wood termites. The two groups cause serious damage but the subterranean one which characterized by a large colony numbering of several million individuals, (Ahmed, 2003, El Sebay, 1993(a \& b)). Termite (White ants) is an exopterygotous insect, which belong to the order Isoptera, and one of the insects that live in the soil. Nevertheless, termites are not a true ant. Termites are insects, social feed on cellulose and live in communities (Assem, 1980).There are eight species of termites in Egypt, 4 belong to genus Psammotermes. These types are abundant in the arid and semi-arid of Upper Egypt (Hafez, 1980). Subterranean termites, Psammotermes hypostoma (Desneux) has become major urban pest also it has a great economic effect in Egypt due to the large damage of the buildings, rural brick mud, timber farmed and furniture caused by it (Beal, 1979; Ahmed and El - Sebay, 2008). The financial damage that caused by termites has stated (Rizk et al., 1982., Ahmed1997 and El- Sebay, 2008, that the costs associated with termite damage and control in buildings in the New Valley only about 200,000 EP in Fayoum governorate, estimated to be about 5 million EP. While amounted to be 6 million in Aswan Governorate. The insecticide Oftanol, Chlorpyrifos, Carbofuran and Permethrin registered to use against termites in new commercial agriculture (Pearce, 1997). There is limited evidence for the presence of neurological effects from chronic exposure to low levels of chlorpyrifos (Ames et al., 1989). Nevertheless, heavy use leads to different damage, including environmental pollution, resistance of pest to chemical pesticides, pest resurgence, secondary pest propagation and direct hazard to users. The solution of these problems lies in finding and developing rational environmental strategy for the management of pests and which is referred to as integrated pest management (IPM). Therefore, it is essential to find alternative ways to manage termites, these ways must be safe, cheap and available (Logan et al., 1990). Such as biological control, by using fungi which is very effective on many types of termites and beneficial (Milner and Staples, 1996; Milner et al., 1996 and Milner., 2003). The mode of action of an entomopathogen is difficult because it is possible for a small amount of vaccine to spread all over the nest before discovery, resulting in an epidemical condition (Kramm et al., 1982). Lenz, (2005) mention that Beauveria bassiana, (Ballsamo)Vuillemin and Metarhizium anisopliae (Metschnikoff) can influence with the impact of slow-acting as bio control agent on the termite community. 


\section{MATERIALS AND METHODS: -}

\subsection{The study site and the fungus used in the study:-}

This study was carried out at South Valley University (svu), carried out at Plant Protection Department, the field experiments were carried out at the agriculture faculty research farm. Metarhizium anisopliae (Metschnikoff), Beauveria bassiana (Ballsamo) were brought from the Assuit universities and Aspergillus niger were obtained from the microbial lab of the SVU.

\subsection{The insect collection: -}

The sand subterranean termites, P.hypostoma (Desn).were collected from the site of infection at (SVU) using EL-Sebay modified trap. The workers were removed from the trap using a soft brush and save them in Petri dishes with pieces of paper providing wet cardboard as a source of cellulose with the necessary termites' humidity for seven days in incubator adjusted at $27 \pm 1^{\circ} \mathrm{C}$. The daily inspection carried out and eliminated dead or moribund individual. The healthy workers were used to the evaluation.

\subsection{Preparation of conidial suspension: -}

The conidial aggregations were suspended in distilled water with $0.01 \%$ tween 80 percentage. The suspensions were a vortex for $5 \mathrm{~min}$. the concentration of suspensions was determined using a Neubauer hemocytometer under Steiror microscopy. The concentrations were diluted from the conidial suspensions to range of $4 \times 10^{6}, 2 \times 10^{6}$ and $1 \times 10^{6}$ spores $/ \mathrm{ml}$.

\subsection{The laboratory bioassay of the entomopathogenic fungi:-}

The bioassay was conducted in $55 \times 15 \mathrm{~mm}$ Petri dishes after that $40 \mathrm{~mm}$ diameter filter pepper (grade 1 Whatman) dapping in the concentration of $4 \times 10^{6}, 2 \times 10^{6}$ and $1 \times 10^{6}$ conidia $/ \mathrm{ml}$, and put in the Petri dishes. Each concentration was applied three replicates; ten termite workers were add to each replicate. All replicates incubated at $28^{\circ} \mathrm{C}$. At the period 7,14 and 21 days, with counted the dead termites.

\subsection{Experimental Field studies to entomopathogenic fungi}

\subsubsection{Culture media: -}

The fungus was propagated on rice. $1 \mathrm{~kg}$ of Rice was washed and parboiled than divided to $100 \mathrm{~g}$ and put into the bag. The bag was closed with the cotton stopper. The bags were autoclaved at $121^{\circ} \mathrm{C}$ for 20 min. after that, the bags were inoculated with fungal disc from growing fungi on PDA than incubated in an incubator at $28^{\circ} \mathrm{C}$ and $75-85 \% \mathrm{RH}$ for 18 -day.

\subsection{Preparation conidial suspensions and} traps: -

The spores harvested by pouring bags with conidia in distilled water with $0.1 \%$ tween 80 and conidia separated by sieving through clean clothes. Spore counts were estimated by using an improved Neubauer hemocytometer. The suspensions were adjusted to concentrations of $4 \times 10^{6}, 2 \times 10^{6}$ and $1 \times 10^{6}$ spores $/ \mathrm{ml}$. the traps were treated with test concentrate after their weight and transported to the infected site.

\subsection{Experiment Design:}

Randomized complete block design (RCBD) was used to carry out the field experiment. The experiment carried out on a $600 \mathrm{~m}^{2}$ divided into three blocks every block divided into 5 equal sized sub-block each sub-block divided into 10 equal sized plot $(2 \times 2 \mathrm{M})$. One trap was treated with a concentration buried in each plot. After 15,30,45,60 and 90 days, traps were removed from sub-block sequentially. Traps sent to the laboratory and removed termite individuals by soft brush, translocation soil and the remaining drying of the trap weighed to calculate the rate of food consumption by termites.

\subsection{Data Analyses:}

Mortalities were calculated for each concentration, observation time and colony combination, and they were corrected for natural mortality (control) with Abbott's correction as the following: corrected $\%=1-(\%$ in treatment- $\%$ in control)/ (100- \% in control) $\times 100$ (Abbott,1925).The values of the $\mathrm{LC}_{50}$ and toxicity index were calculated using Ldp line program. The Duncan test was used to compare the averages of the laboratory evaluation data for fungi by using the SAS program also using ldp line program to estimate the values of the $\mathrm{LC}_{50}$ and toxicity index. Reduction $\%=1$ - [the food consumption (g) of the EL-Sebay modified trap used in the treatment/the food consumption $(\mathrm{g})$ of the EL- Sebay modified trap used in the control] $\times 100$.

\section{Results and Discussions:}

\subsection{The laboratory studies: -}

Table (1) showed that the mean mortality rate of termite workers after treatment with concentrates of spore suspension of M. anisopliae, B.bassiana and A.niger isolates on filter paper. After one week of treatment there was significate difference among concentrate $4 \times 10^{6}$, concentrates $2 \times 10^{6}$ and $1 \times 10^{6}$ but no significate difference among concentrates $2 \times 10^{6}$ 
Mahmoud M.M. Soliman et al., 2019

Table 1. The mean mortility percentage of the subterranean termite p.hypostomma after 7 days, 14 days and 21days from treatment with A.niger B. assiana and M.anisopliae

\begin{tabular}{|c|c|c|c|c|c|}
\hline & \multicolumn{4}{|c|}{ Mean Mortality percentage after treatment } & \multirow[b]{2}{*}{ Mean } \\
\hline & Treatment & $4 \times 10^{6}$ & $2 \times 10^{6}$ & $1 \times 10^{6}$ & \\
\hline \multirow{4}{*}{ After 7 day } & A.niger & $36.6^{\mathrm{BC}}$ & $13.3^{D}$ & $3.3^{\mathrm{D}}$ & $13.3^{\mathrm{B}}$ \\
\hline & B.assiana & $43.3^{\mathrm{BA}}$ & $13.3^{\mathrm{D}}$ & $3.3^{\mathrm{D}}$ & $15.0^{\mathrm{B}}$ \\
\hline & M.anisopliae & $63.3^{\mathrm{A}}$ & $20.0^{\mathrm{DC}}$ & $6.6^{\mathrm{D}}$ & $22.5^{\mathrm{A}}$ \\
\hline & Control & $0.00^{\mathrm{D}}$ & $0.00^{\mathrm{D}}$ & $0.00^{\mathrm{D}}$ & $0.00^{\mathrm{D}}$ \\
\hline \multirow{4}{*}{ After 14 day } & A.niger & $53.3^{\mathrm{BC}}$ & $23.3^{\mathrm{DE}}$ & $10.0^{\mathrm{E}}$ & $22.5^{\mathrm{B}}$ \\
\hline & B.assiana & $73.3^{\mathrm{BA}}$ & $50.0^{\mathrm{BC}}$ & $46.6^{\mathrm{DC}}$ & $43.3^{\mathrm{A}}$ \\
\hline & M.anisopliae & $83.3^{\mathrm{A}}$ & $53.3^{\mathrm{BC}}$ & $23.3^{\mathrm{DE}}$ & $40.83^{\mathrm{A}}$ \\
\hline & Control & $3.3^{\mathrm{E}}$ & $3.3^{\mathrm{E}}$ & $3.3^{\mathrm{E}}$ & $3.3^{\mathrm{E}}$ \\
\hline \multirow{4}{*}{ After 21 day } & A.niger & $76.6^{\mathrm{BA}}$ & $63.3^{\mathrm{BC}}$ & $43.3^{C}$ & $47.5^{\mathrm{B}}$ \\
\hline & B.assiana & $23.3^{\mathrm{A}}$ & $60 . \cdot^{\mathrm{BC}}$ & $43.3^{\mathrm{C}}$ & $50.8^{\mathrm{BA}}$ \\
\hline & M.anisopliae & $26.6^{\mathrm{A}}$ & $83.3^{\mathrm{BA}}$ & $60.0^{\mathrm{BC}}$ & $61.6^{\mathrm{A}}$ \\
\hline & Control & $6.6^{\mathrm{D}}$ & $6.6^{\mathrm{D}}$ & $6.6^{\mathrm{D}}$ & $6.6^{\mathrm{D}}$ \\
\hline
\end{tabular}

*Each mean mortality rate $(\%)$ value represents mean of 3 replicates.

**Means followed by the same superscript are not significantly different (P > 0.05) according to Duncan's Multiple Range Test (DMRT)

and $1 \times 106$ of all treatments. In addition to there was significant difference among M.anisopliae and other fungi B.bassiana (Ballsamo) and A.niger, The fungi M.ansiopliae more effectiveness than B.bassiana and A.niger which the mortality rates were $22.5 \%, 15.0 \%$ and $13.3 \%$ to M.ansiopliae , B.bassiana and A.niger, respectively. After 14 days of treatments with increased period the result shows no significates difference among concentrates $4 \times 106$ and $2 \times 10$ but there were significates difference with concentrate $1 \times 106$ compared with control. Between treatments M.anisopliae have significant difference also have significant difference among concentrate $4 \times 106$ and other concentrates to fungi A.niger. Three period after 21 days of treatment, the results show no significant difference among concentrates $2 \times 106$ and $1 \times 106$ for B.bassiana treatments, while no significant difference among concentrates $4 \times 10^{6}$ and $2 \times 10^{6}$ for M.anisopliae and A.niger treatments. There was significant deference between total mean to M.anisopliae and A.niger. In addition to that; there are no significant differences between the A.niger and B.bassiana. Rustles agree with Solaiman and Abd EL- Latif (2014) The mortilaty rates were 2.6, 84 and $100 \%$ respectively during 7 days of termite, $P$. hypostoma workers treatment with $M$. anisopliae spores. The mortality rate was the least in the first two days of treatment and Increased rapidly in the following days. M. anisopliae at $10^{8}$ spores $/ \mathrm{ml}$ caused 57.5, 77 and $100 \%$ mortality among treated Coptotermes formosanus (Shiraki) on day 7, 14 and 21, respectively, (Sileshi et al., 2012). Mburu et al. (2009) found that Percentage mean mortalities of worker termite incident by isolates of $M$. anisopliae were significantly more than those incidents by isolates of $B$. bassiana at a concentration of $10^{7}$ conidia $\mathrm{ml}^{-1}$. Brousseau et al. (1996), Dumas et al. (1994) and Kershaw et al. (1999) suggested that the destruxins (dtxs), produced by M. anisopliae may be serious virulence agent to speed up the dead infected insects. Nevertheless, B. bassiana produce exoproteases, the cyclic peptide beauverin Hamill et al. (1969). Aihetasham et al. (2015) studied that impact Aspergillus parasiticus against workers termites Coptotermes hei, The mortality rate was higher with long period of exposure to spores. The mortality of termites increased by degrees and constantly from day 1 to day 8 from treated, this fungus worked slowly and effectively against termite's workers. Figure (1 A and D) shows the treatment of both the fungus M.anisopliae and A.niger, respectively during the implementation of the experiment. As shown in Figure B and E the fungal growth for both M.ansiopolia and A.niger, respectively, under the Binocular microscope, which shows the heavy growth of fungus on the workers compared to the fungal growth of A.niger. Figure C and $\mathrm{F}$ shows the penetration worker cuticle by hyphae M.anisopliae and A.niger respectively, under scanning electron microscope (SEM). Our results agree with Yendol and Paschke (1965), Bao and Yendol (1971) and Hanel (1981) stated that Entomopathogenic fungi effect on host by permeation cuticle and occur death to host. Figure (2) shown toxicity line for fungi that illustrated them the fungi M.anisopliae was more effective than B.bassiana and other fungi.While B.bassiana was more effective than A.niger. The $\mathrm{LC}_{50}$ for three fungi were $3.278 \times 10^{6}, 4.6526 \times 10^{6}$ and $5.4982 \times 10^{6}$ for M.anisopliae, B.bassiana and A.niger, respectively .These results agreement with Singha et al. (2011) reported that M.anisopliae was achieved higher 
Scientific Journal of Agricultural Sciences 1 (1): 21-29, 2019

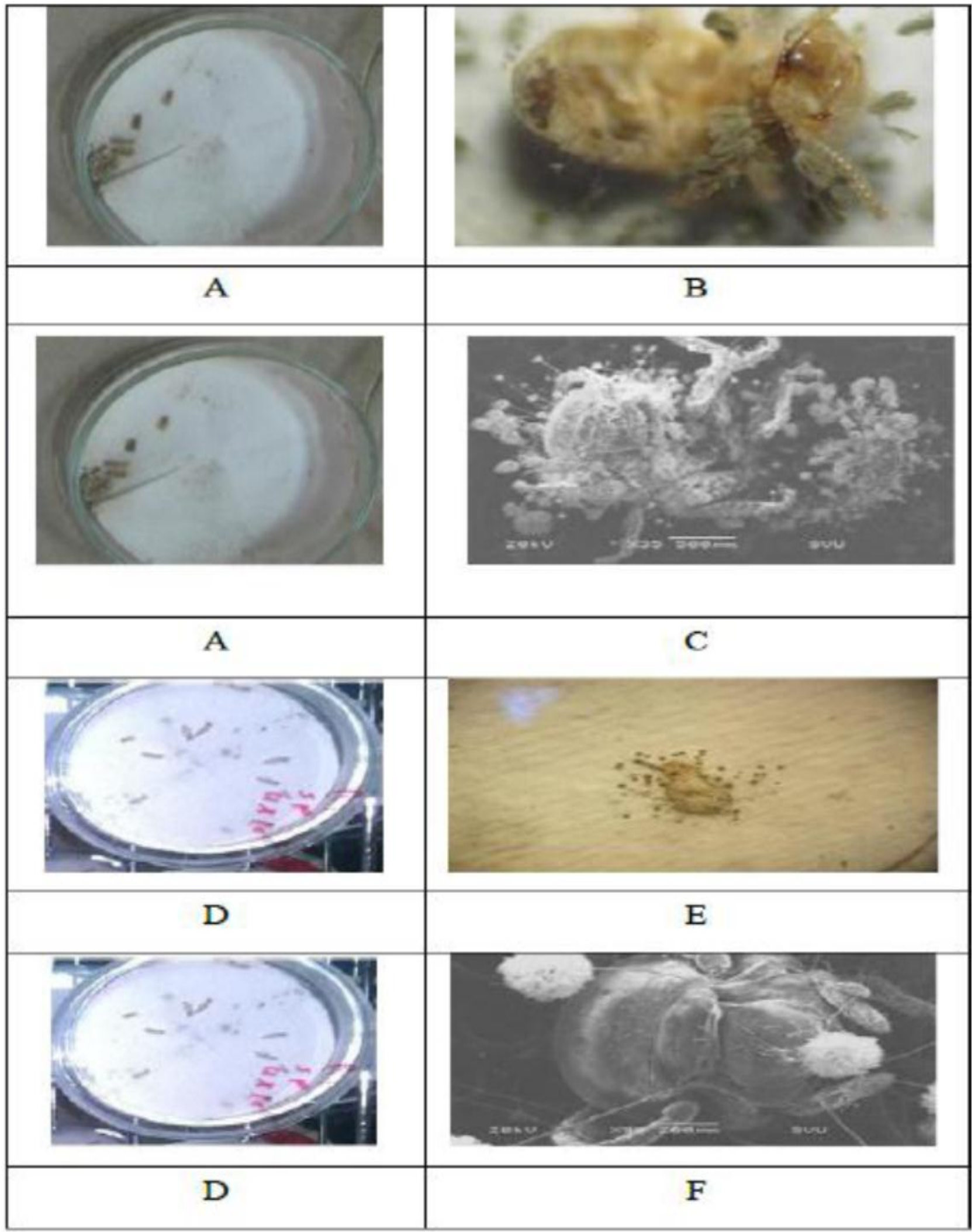

Fig 1. Entomopathogenic fungi M.anisopliae and A.niger growth on worker of P.hypostoma (Desneux). Where: $A=$ worker treatment with M.anisopliae $B=$ mycelium M.anisopliae under Binocular microscope , $\mathrm{C}=$ mycelium M.anisopliae under scanning electron microscope(SEM), $D=$ worker treatment with A.niger, $E=$ mycelium A.niger under Binocular microscope and $\mathrm{F}=$ mycelium A.niger under scanning electron microscope (SEM). 


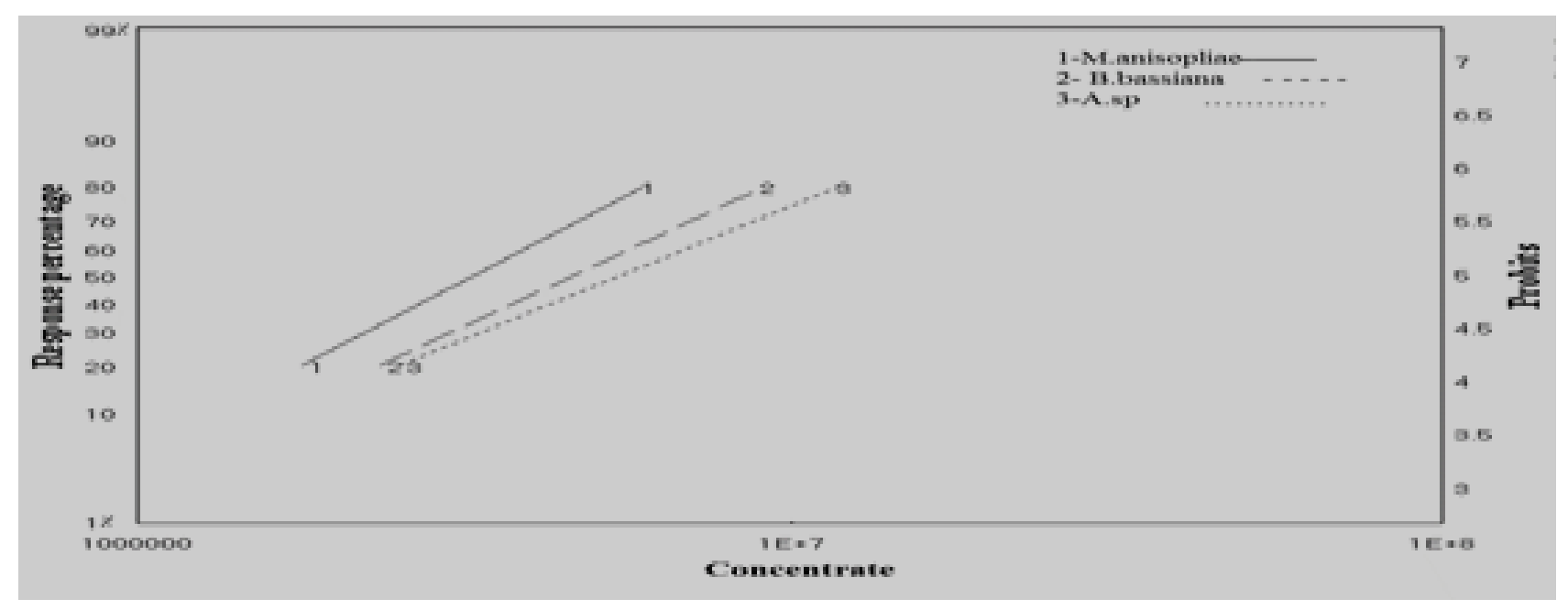

Fig2. Toxicity line for M.anisopliae, B.bassiana and A.niger after 7 day from treatment.

mortality compared with B.bassiana when used application a topical applied on tea termite Microtermes obesi (Holmgren) workers.. Sun et al. (2002). The potential use of $M$. anisopliae as a biological control agent against subterranean termites is being challenged, because the disease remained at an enzootic level in laboratory sand arenas and the fungus showed a reduced survival rate in the presence of termites Chouvenc et al. (2008). Hoque et al. (2016) found that M.anisopliae the mortality rate was $43.28-72.24 \%$ after 7 days from treatment these rustle agree with our study. Entomophogenic fungi infect direct penetration of the cuticle.

\subsection{Eperimental field studies:-}

Experimental Field studies to entomopathogenic fungi. The data in Table (2) explain the reduction percentages in the treated traps with fungi suspension (as consumption, food by worker), after 15 days were in A.niger, B.bassina and M.anisopliae at concentrations $1 \times 106$ spores $/ \mathrm{ml}$ were $100,44.50$ and $31.26 \%$, respectively.

While, at concentrations $2 \times 10^{6}$ and $4 \times 10^{6}$ spores $/ \mathrm{ml}$ were $100 \%$ for A.niger, B.bassina, on the other hand in case of M.anisopliae were 64.51 and 73.54 , respectively.

After 30 days Table (3) the reduction percentages were at the concentration $1 \times 10^{6}$ spores $/ \mathrm{ml} 38.54$, 36.38 and 7.49 percentage for A.niger, B.bassiana and M.anisopliae, respectively. Nevertheles at the concentration $2 \times 10^{6}$ spores $/ \mathrm{ml}$ the reduction percentages was $44.68,38.54$ and $32.25 \%$, while the concentration $4 \times 10^{6}$ spores $/ \mathrm{ml}$, was $85.79,81.00$ and $81.00 \%$ for A.niger, B.bassiana and M.anisopliae, respectively.

Table 2. The reduction (\%) of B.bassiana, A.niger and M.anisopliae against the sand subterranean termite, $P$. hypostoma, by using foraging activity on El-Sebay modified traps, after 15 days of traps treatment.

\begin{tabular}{|c|c|c|c|c|c|c|}
\hline \multirow[t]{2}{*}{ Conc. spoers /ml } & \multicolumn{2}{|c|}{ A. niger } & \multicolumn{2}{|c|}{ B.bassiana } & \multicolumn{2}{|c|}{ M.anisopliae } \\
\hline & Food. Cons & Red.* [\%] & Food.Cons & Red.*[\%] & Food. Cons & Red.* [\%] \\
\hline The control & 42 & 0 & 42 & 0 & 42 & 0 \\
\hline $1 \times 10^{6}$ & 0.00 & 100.00 & 23.33 & 44.50 & 29.00 & 31.26 \\
\hline $2 \times 10^{6}$ & 0.00 & 100.00 & 0.00 & 100.00 & 15.00 & 64.51 \\
\hline $4 \times 10^{6}$ & 0.00 & 100.00 & 0.00 & 100.00 & 11.33 & 73.54 \\
\hline
\end{tabular}

\footnotetext{
*The reduction percentages recorded as the rate of food consumption (g) from traps by the workers.
} 
Table 3. The reduction (\%) of B.bassiana, A.niger and M.anisopliae against the sand subterranean termite, $P$. hypostoma, by using foraging activity on El-Sebay modified traps, after 30 days of traps treatment.

\begin{tabular}{|c|c|c|c|c|c|c|}
\hline \multirow[t]{2}{*}{ Conc. spoers /ml } & \multicolumn{2}{|c|}{ A.niger } & \multicolumn{2}{|c|}{ B.bassiana } & \multicolumn{2}{|c|}{ M.anisopliae } \\
\hline & Food. Cons & Red.* [\%] & Food. Cons & Red.*[\%] & Food. Cons & Red.* [\%] \\
\hline The control & 72.33 & 0.00 & 72.33 & 0.00 & 72.33 & 0.00 \\
\hline $1 \times 106$ & 44.67 & 38.54 & 46.13 & 36.38 & 66.77 & 7.46 \\
\hline $2 \times 106$ & 40.37 & 44.68 & 44.67 & 38.54 & 49.00 & 32.25 \\
\hline $4 \times 106$ & 10.07 & 85.79 & 13.67 & 81.00 & 13.67 & 81.00 \\
\hline
\end{tabular}

*The reduction percentages were recorded as the rate of food consumption (g) from traps by the workers.

Table (4) showed the reduction percentages after 45 days at the concentrate $1 \times 106$ spores/ml were 29.99, 33.40 and $8.11 \%$ for A.niger, B.bassiana and M.anisopliae, respectively. While, at the high concentrations $2 \times 106$ spores/ml and $4 \times 106$ spores/ml the reduction percentages for A.niger, B.bassiana and M.anisopliae were 43.91, 53.72and $34.60 \%$ at the concentrate $2 \times 10^{\wedge} 6$ spores $/ \mathrm{ml}$, respectively and $80.85,73.23$ and $79.08 \%$ for $4 \times 106$ spores/ml, respectively.

Table 4. The reduction (\%) of B.bassiana, A.niger and M.anisopliae against the sand subterranean termite, $P$. hypostoma, by using foraging activity on El-Sebay modified traps, after 45 days of traps treatment.

\begin{tabular}{|c|c|c|c|c|c|c|}
\hline \multirow[t]{2}{*}{ Conc spoers $/ \mathrm{ml}$} & \multicolumn{2}{|l|}{ A.niger } & \multicolumn{2}{|l|}{ B.bassiana } & \multicolumn{2}{|l|}{ M.anisopliae } \\
\hline & Food. Cons & Red.*[\%] & Food. Cons & Red.*[\%] & Food. Cons & Red.*[\%] \\
\hline The control & 80.33 & 0 & 80.33 & 0 & 80.33 & 0 \\
\hline $1 \times 10^{6}$ & 56.28 & 29.99 & 53.53 & 33.40 & 73.83 & 8.11 \\
\hline $2 \times 10^{6}$ & 44.91 & 43.91 & 37.37 & 53.72 & 52.47 & 34.60 \\
\hline $4 \times 10^{6}$ & 15.36 & 80.85 & 21.67 & 73.23 & 16.83 & 79.08 \\
\hline
\end{tabular}

*The reduction percentages recorded as the rate of food consumption (g) from traps by the workers.

After 60 days Table (5), at the concentration of $1 \times 106$ spores $/ \mathrm{ml}$, the percentages of reduction for A.niger, B.bassiana and M.anisopliae were 22.77, 32,53 and $4.94 \%$, respectively. At the concentration
$2 \times 106$ spores $/ \mathrm{ml}$, the reduction percentages were $34.56,46.68$ and $28.82 \%$, respectively. In addition. $74.29,66.00$ and $61.42 \%$, at the concentration $4 \times 106$ spores/ml, respectively.

Table 5. The reduction (\%) of B.bassiana, A.niger and M.anisopliae against the sand subterranean termite, $P$. hypostoma, by using foraging activity on El-Sebay modified traps, after 60 days of traps treatment.

Conc. spoers $/ \mathrm{ml}$ A.niger B.bassiana M.anisopliae

\begin{tabular}{ccccccc} 
& Food. Cons & Red.*[\%] & Food. Cons & Red.*[\%] & Food. Cons & Red.*[\%] \\
\hline The control & 87.33 & 0.00 & 87.33 & 0.00 & 87.33 & 0.00 \\
$\mathbf{1 \times 1 \mathbf { 1 0 } ^ { \mathbf { 6 } }}$ & 67.40 & 22.77 & 59.17 & 32.53 & 83.00 & 4.94 \\
$\mathbf{2 \times 1 0 ^ { \mathbf { 6 } }}$ & 56.97 & 34.56 & 46.83 & 46.68 & 62.23 & 28.82 \\
$\mathbf{4 \times 1 0 ^ { \mathbf { 6 } }}$ & 22.35 & 74.29 & 29.76 & 66.00 & 33.96 & 61.42
\end{tabular}

*The reduction percentages recorded as the rate of food consumption $(\mathrm{g})$ from traps by the workers. 
The reduction percentage after 90 days, Table (6) explained that the reduction at the concentrates $1 \times 106$ spores $/ \mathrm{ml}, 9.33,4.91$ and $2.24 \%$, for A.niger, B.bassiana and M.anisopliae, respectively. On the other hand, at the higher concentrations $2 \times 106$ spores $/ \mathrm{ml}$ and $4 \times 106$ spores $/ \mathrm{ml}$ the reduction percentages were 25.93 , 19.43 and $11.85 \%$ for $2 \times 106$ spores $/ \mathrm{ml}$ and $61.52,35.54$ and $20.06 \%$ at $4 \times 106$ spores $/ \mathrm{ml}$ for A.niger, B.bassiana and M.anisopliae, respectively. In checking the results, it is clear that A.niger was more effective than B.bassiana,
B.bassiana more effective than M.anisopliae. The reduction rate is gradually decreasing as result the workers do not avoid of traps treated at concentrations. This indicates the persistence of feeding in the treated traps, which would lead to the spread of spores among the individuals of the colony and the occurrence of an epizootic. Culliney and Grace (2000) indicated that the use of baits strategies increased effective of spread the fungi spores between individuals of colony and cause an epizootic. Also Milner et al. (1996)

Table 6. The reduction (\%) of B.bassiana, A.niger and M.anisopliae against the sand subterranean termite, P. hypostoma, by using foraging activity on El-Sebay modified traps, after 90 days of traps treatment.

\begin{tabular}{llll}
\hline Conc. spoers $/ \mathrm{ml}$ & A.niger & B.bassiana & M.anisopliae
\end{tabular}

\begin{tabular}{ccccccc} 
& Food.Cons & Red.*[\%] & Food.Cons & Red.*[\%] & Food.Cons & Red.*[\%] \\
\hline The control & 89.33 & 0 & 89.33 & 0 & 89.33 & 0 \\
$\mathbf{1 \times 1 0 ^ { \mathbf { 6 } }}$ & 81.00 & 9.33 & 84.93 & 4.91 & 87.33 & 2.24 \\
$\mathbf{2 \times 1 0 ^ { \mathbf { 6 } }}$ & 66.20 & 25.93 & 71.98 & 19.43 & 78.70 & 11.85 \\
$\mathbf{4 \times 1 0 ^ { \mathbf { 6 } }}$ & 34.31 & 61.52 & 57.67 & 35.54 & 71.40 & 20.06 \\
& & & & & &
\end{tabular}

*The reduction percentages recorded as the rate of food consumption (g) from traps by the workers.

stated the "trap and treat" system as one of the tactic in bait technology. This method consists of catch and blockade part of a termite population, treating the individuals with pathogenic conidia and releasing them into their nest of origin, Enabling them to spread the conidia to the entire nest. Also, Wright et al. (2005) used strain from M. anisopliae for controlling alates of the Formosan subterranean termite, Coptotermes formosanus (Shiraki). Mention that the transfer of inoculum from infected workers to uninfected nest mates, $62.8 \%$ of the workers died in $21 \mathrm{~d}$ when only $20 \%$ of the workers been inoculated. On the other hand, the mortality in alates were $100 \%$ when sawing the fungi spores on grassy. Singha et al. (2011) applied of the entomopathogenic fungi $\mathrm{B}$. bassiana and $\mathrm{M}$. anisopliae on the tea termite Microtermes obesi (Holmgren), the fungi shown promising results to control termite, in addition to B. bassiana was more effective than $M$. anisopliae. Wang and Powell (2004) reported that the M. anisopliae did not have a repellent effect on against the eastern subterranean termite, Reticulitermes flavipes (Kollor) and the Formosan subterranean termite, Coptotermes formosanus(Shiraki), when applied with cellulose bait. Therefore, In our study, the run-down in the percentage of reduction in traps treated with concentrations of the M. anisopliae may be due to this reason. In addition, our study showed that the reduction percentages for trap treated with concentration of $\mathrm{A}$. niger were height due to not attack by workers, perhaps because the fungi A. niger has a repellent or an antipathetic effect to worker. This result is consistent with the observation Aihetasham et al. (2015) indicated that the A. parasiticus has repellent effect against the workers of Coptotermes heimi. Moharram, et al. (1992) isolated A. niger from $\mathrm{P}$. hypostoma workers.

\section{REFERENCES}

Abbott WS (1925). A method of computing the effectiveness of an insecticide. J. Econ. Entomol. 4: 265-267

Ahmed HM (2003). Ecological and control studies on subterranean termites under Fayoum conditions. $\mathrm{Ph}$. D. Thesis, fac. Agric fayoum, cairo university.140PP.

Ahmed HM, EL-Sebay Y (2008). Distribution and damage assessment of subterranean termites with reference to forging behavior and population fluctuation at EL-Giza Governorate Alexandria journal of Agricultural Research. 53(1):55-62.

Ahmed HM (1997). Ecological studies and control of harvester subterranean Termites, 
Anacanthotermes ocharchceus (Burm) At Fayoum Governorate M . SC. Thesis Fac. Agric.Fayoum, Cairo University.pp.77

Aihetasham A, Qayyum F, Xaaceph M (2015). Pathogenicity of Aspergillus parasiticus against Coptotermes heimi (Wasmann). Punjab Univ. J. Zool., 30(2): 51-55.

Ames RG, Brown SK, Rosenberg J, Jackson RJ, Stratton JW, Quenon SG (1989). Health symptoms and occupational exposure to flea control products among California pet handlers. Am Ind Hyg Assoc J;50:466-72.

Asogwa EU, Okelana FA, Ndubuaku TCN, Mokwunye IU (2009). The termicidal effects of Chlorpyrifos 48 EC, Endosulfan 35 EC, Dichlorvos $1000 \mathrm{EC}$ and Diazinon $600 \mathrm{EC}$ against termites in South-West Nigeria. African Journal of Biotechnology, 8(1)..

Assem MA (1980). Termites on vegetables sociobiology,5(2): 162-162.

Bao LL, Yendol WG (1971). Infection of the eastern subterranean termite, eticulitermes flavipes (Kollar) with the fungus Beauveria bassiana (Balsamo) Vuill. Bio Control, 16(3), 343352.tomologist, 101(5), 460-462.

Beal RH (1979). Preventing termite attack by adding insecticides to particle board, hard board and plywood adhesive in U.S.A., Forst product journal. 22(12)22-34

Brousseau C, Charpentier G, Belloncik S (1996). Susceptibility of Spruce Budworm, Choristoneura Fumiferana Clemens, to Destruxins, Cyclodepsipeptidic Mycotoxins of Metarhizium anisopliae. Journal of invertebrate pathology, 68(2), 180-182.

Chouvenc T, Su NY, Elliott ML (2008). Interaction between the subterranean termite Reticulitermes flavipes (Isoptera: Rhinotermitidae) and the entomopathogenic fungus Metarhizium anisopliae in foraging arenas. Journal of Economic Entomology, 101(3), 885-823.

Culliney TW, Grace JK (2000). Prospects for the biological control of subterranean termites (Isoptera: Rhinotermitidae), with special reference to Coptotermes formosanus. Bulletin of entomological research, 90(1), 9-21.

Delate KM, Grace JK, Tome CH (1995). Potential use of pathogenic fungi in baits to control the Formosan subterranean termite (Isopt., Rhinotermitidae). Journal of Applied Entomology, 119(1-5), 429-433.

Dumas C, Robert P, Pais M, Vey A, Quiot JM (1994). Insecticidal and cytotoxic effects of natural and hemisynthetic destruxins. Comparative Biochemistry and Physiology Part C: Pharmacology, Toxicology and Endocrinology, 108(2), 195-203.
El-Sebay Y (1993a). Ecological studies on the colonies of the harvester termite Anacanthotermes ochraceus (Burm). in Egypt. Bull. Ent. Soc. Egypt, (47) : 48-54.

El-Sebay Y (1993b). Evaluation of soil treatment with certain insecticides for subterranean termite control. Bull. ent. Soc.,Egypt. Econ. ser.20 (47) : 4758.

El-Sebay YM (2008). Studies on subterranean termite in Aswan, survey and damage assignment Egypt.J.Agric.res 86(1):225-236

Hafez M (1980). Highlights of the termite problem in Egypt sociobiology,5 (2):147-154

Hamill RL, Higgens CE, Boaz HE, Gorman M (1969). The structure of beauvericin, a new depsipeptide antibiotic toxic to Artemia salina. Tetrahedron Letters, 10(49), 4255-4258.

Hanel H (1981). A bioassay for measuring the virulence of the insect pathogenic fungus Metarhizium anisopliae (Metsch.) Sorok. (fungi imperfecti) against the termite Nasutitermes exitiosus (Hill)(Isoptera, Termitidae). Journal of Applied Entomology, 92(15), 9-18.

Hoque AKMR, Aslam AFM, Ahmed M, Mamun MSA, Howlader AJ (2016). Laboratory and Field Evaluation of an Entomopathogenic Fungus Formulation-Bioterminator (Metarhizium Anisopliae Metchnikoff) against Termite Infesting Tea. Journal of Tea Science Research, 6.

Kershaw MJ, Moorhouse ER, Bateman R, Reynolds SE, Charnley AK (1999). The role of destruxins in the pathogenicity of Metarhizium anisopliae for three species of insect. Journal of invertebrate pathology, 74(3), 213-223.

Kramm KR, West DF, Rockenbach PG (1982). Termite pathogens: transfer of the entomopathogen Metarhizium anisopliae between Reticulitermes sp. termites. Journal of Invertebrate Pathology, 40(1), 16.

Lenz M (2005). Biological control in termite management: the potential of nematodes and fungal pathogens. In Proc. Fifth International Conference on Urban Pests, Malaysia (pp. 47-52).

Logan JW, Cowie RH, Wood TG (1990). Termite (Isoptera) control in agriculture and forestry by nonchemical methods: a review. Bulletin of entomological research, 80(03), 309-330.

Mao L, Henderson G, Scherer CW (2011). Toxicity of seven termiticides on the Formosan and eastern subterranean termites. Journal of economic entomology, 104(3), 1002-1008. ISO 690

Mburu DM, Ochola L, Maniania NK, Njagi PGN, Gitonga LM, Ndung'u MW, Hassanali A (2009). Relationship between virulence and repellency of entomopathogenic isolates of Metarhizium anisopliae and Beauveria bassiana to the termite 
Macrotermes michaelseni. Journal of Insect Physiology, 55(9), 774-780.

Milner RJ(2003). Application of biological control agents in mound building termites (Isoptera: Termitidae)-Experiences with Metarhizium in Australia. Sociobiol., 41: 412-428.

Milner RJ, Staples JA (1996). Biological control of termites: results and experiences within a CSIRO project in Australia. Biocontrol Science and Technology (United Kingdom).

Milner RJ, Staples JA, Lenz M (1996). Options for termite management using the insect pathogenic fungus Metarhizium anisopliae. Document-the International Research Group on Wood Preservation (Sweden).

Moharram AM, Bagy MMK, Abdel-Galil FA (1992). Fungi associated with the sand termite Psammotermes hypostoma (Desneux) in Assiut, Egypt. Mycologia, 84(6), 930-935.

Pearce MJ (1997). Termites, biology and pest management.CAB International U.K., p. 172.

Rizk, M. M., Khalil, F .M. and Maher ,A.A.(1982). Assessment of damage due to termite Egypt, New Valley Governorate ,western desert. Assuit J. Agric. Sci 13(3):23-100.

Sileshi AW, Sori, Dawd M (2012). Laboratory evaluation of entomopathogenic fungi Metarhizium anisopliae and Beauveria bassiana against termite, Macrotermes (Isoptera: Termitidae). Asian J. Plant
Sci., Asian network for scientific information, 1-10 opined.

Singha D, Singha B, Dutta BK (2011). Potential of Metarhizium anisopliae and Beauveria bassiana in the control of tea termite Microtermes obesi Holmgren in vitro and under field conditions. Journal of pest science, 84(1), 69-75.

Solaiman RHA, Abd El-Latif NAA (2014). Isolation and Pathogenicity of the Fungus Metarhizium anisopliae (Metschnikoff) Against the Subterranean Termite, Psammotermes hybostoma Desneux (Isoptera: Rhinotermitidae). Egyptian Journal of Biological Pest Control, 24(2), 329.

Sun J, Fuxa JR, Henderson G (2002). Sporulation of Metarhizium anisopliae and Beauveria bassiana on Coptotermes formosanus(shiraki) and in vitro. Journal of invertebrate pathology, 81(2), 78-85.

Wang C, Powell JE (2004). Cellulose bait improves the effectiveness of Metarhizium anisopliae as a microbial control of termites (Isoptera: Rhinotermitidae). Biological Control, 30(2), 523529.

Wright MS, Raina AK, Lax AR (2005). A strain of the fungus Metarhizium anisopliae for controlling subterranean termites. Journal of economic Entomology, 98(5), 1451-1458.

Yendol WG, Paschke JD (1965). Pathology of an Entomophthora infection in the eastern subterranean termite Reticulitermes flavipes (Kollar). Journal of Invertebrate Pathology, 7(4),414-422.

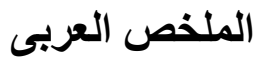

المكافحة البيولوجية للنمل تحت ارضى الأبيض (Psammotermes hypostoma)

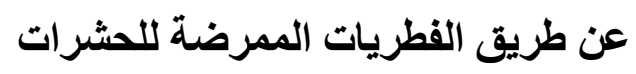

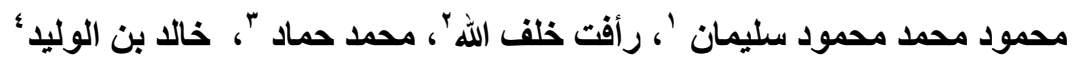

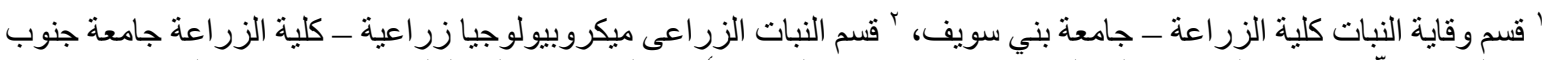

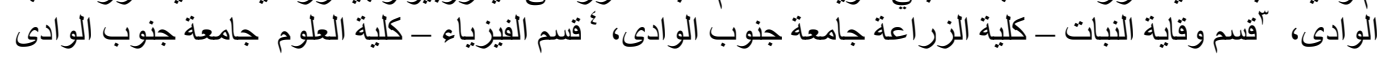

أجريت هذه الدراسة لتحديد تأثير الفطريات المسببة للأمر اض Beauveria ) ، M.ansiopliae Metarhiziuim anisopliae

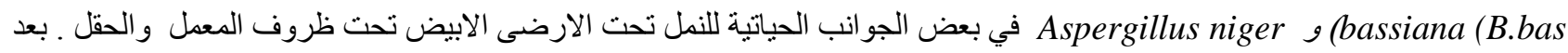

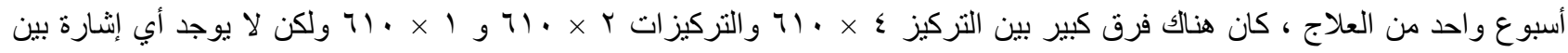

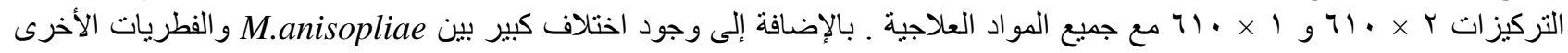

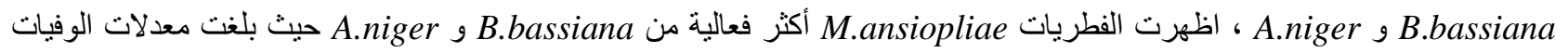

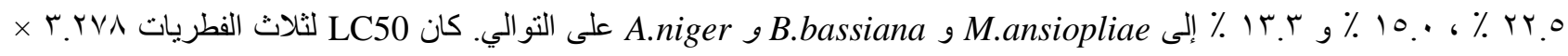

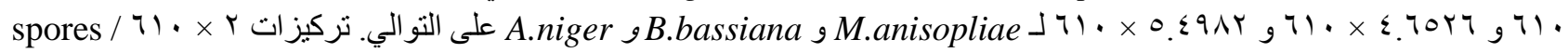

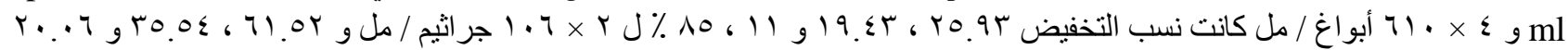

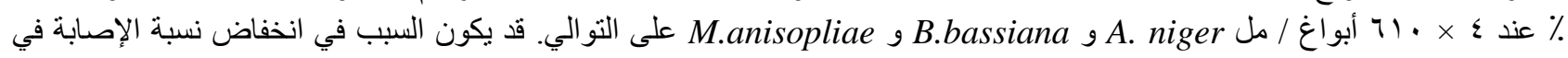

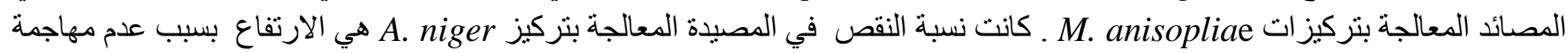

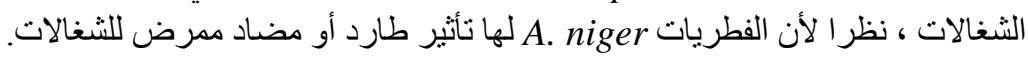

